of their force. If the corps are to continue in peace to play any considerable part in the youth service, they must greatly develop tho educational, social, and recreative side of their work. This suggests that the general responsibility for their administration, direction and finance should be turned over to the Board of Education and the local education authorities. At the same time it is essential that the Service Departments should prescribe and retain the supervision of both the content and the standards of the pre-service training.

The position of the National Association of Training Corps for Girls differs materially from that of the boys' pre-service training organizations. Whilo it provides a certain amount of general pre-service training, it is not attached to any one branch of the Armed Forces and has never been under the control of the Service Departments. It is presumably an organization which, by the provision of a general type of training, offers to girls the opportunity of yoluntarily continuing their education irrespective of a specific objective. It is desirable that the National Association of Training Corps for Girls should continue in existence after the War as a uniformed organization. 'The Board of Education and the local education authorities should extend to it the same degree of support as is given to other voluntary organizations.

The youth committees which were set up after the issue of Circular 1486 differ from one another both in constitution and efficiency. The essential qualification for membership is youthfulness, if not in years at least in spirit. It is far from certain that this 'young-mindedness' has been sufficiently insisted upon. Taking the broad view, however, the experiment of laying joint obligations on the local education authorities and the voluntary organizations has been successful, and the co-partnership needs increasing to the fullest possible extent. After three years of experiment, a useful function would be served if the Board of Education collected and issued for the guidance of all youth committees the information which by now must be available about the ways in which this very practical form of education in citizenship has developed.

The Council's broad survey of the field of youth is important for the emphasis it lays on the 'wholeness of life'. The home, school, employment, leisure, service and religion all interact for the development of intellect, skill, personality and character, and tho Youth Advisory Couneil has wisely insisted that the whole upbringing of a boy or girl shall be in the widest sense educational. This is all to the good, for frequently do we end our arguments concerning the various failings of present-day youth-from lack of social sense to that of musical appreciation-with the everlasting demand, education and more education. By their challenging and long-sighted recommenda. tions in the interests of youth, the Youth Advisory Council, fairly representing the opinion of the majority of youth workers in Great Britain, has presented the President of the Board of Education with advice to which he will no doubt pay the closest attention. Much depends upon it.

\section{INDUSTRY AND SOCIETY}

\section{RELATION TO THE NATION}

A SIGNIFICANT indication of the widespread interest in the organization of industry after the War and the relations between industry and government can be seen in the references to these questions at recent important company meetings such as those of Boots Pure Drug Company, the Associated Portland Cement Manufacturers and Associated Electrical Industries. At the last-named meeting, Sir Felix Pole emphasized the efficiency and adaptability of industry as it is now organized; he leaned towards a planned organization of the cartel type, much as Lord McGowan did in a recent article in the Sunday Times on the place of combines and cartels. These and other addresses in the past few months show that the place and functions of private enterprise in the national economy are under re-examination.

Many factors have contributed to this position. War-time developments and the experience of wartime controls, the growth of restrictive practices, for all their denunciation by industrial leaders of high repute, our closer contacts both with Soviet Russia and with the United States--the recent visit to Great Britain of Mr. Eric A. Johnson, president of the Chamber of Commerce of the United States, has demonstrated some important differences in the British and the American view of creative private enterprise-have all played their part, and the general point of view has been well put by $\mathrm{Mr}$. Herbert Morrison, particularly in his speech at Leeds in April. A case can be made for private enterprise in appro. priate fields, as well as a powerful case for public enterprise. There is no case whatever for private un-enterprise, or for private control without the spur of free competition or of real sccial purpose.

That much will be generally admitted, particularly by scientific workers concerned with the prosecution of an adequate programme of scientific and industrial research as an integral part of post-war plans. The fresh scrutiny of private enterprise to-day, in spite of recognized shortcomings of State control during the War in certain directions, is due to the widespread appreciation that large sections of British industry were anything but enterprising in the twenty years between the two Wars. Attempts in some reports on reconstruction, such as those of the Federation of British Industries, the Association of British Chambers of Commerce, and, to a lesser extent, the statement on "A National Policy for Industry", to gloss over this record, and a timidity of outlook simultaneously apparent have not allayed this concern. On the contrary, they have stimulated fresh fears that such important associations are looking to policies of restriction and monopoly destined in the long run to be as fatal to their own interests as to the policy of full employment which public opinion, in Great Britain as elsewhere, is coming insistently to dermand.

That much clearly emerges from the survey "Industry After the War. Who is Going to Run It ?" which Charles Madge has produced as the first of the 
"Target for To-morrow" Series*. But neither Mr. Madge in his summary, nor Sir William Beveridge in his introduction, goes any deeper into the fundamental issues than the statements already criticized. The Unilever paper, "The Problem of Unemployment", the more recent Nuffield College paper, "Employment Policy and the Organization of Industry after the War", and the report of the SubCommittee of the Liberal Party on the relation of the State to industry, it is true, go nearer to the roots of the matter. Even in these, however, no real attempt is made to sort out the fundamental issues and to ask the all-important questions regarding the relations of Government and industry before an attempt is made to define the targets or formulate the lines of policy.

Such fundamental thinking is an essential preliminary, and without it plausible schemes for the self-government of industry are more likely to be snares or delusions than contributions to the solution of the problem of full employment. The fact is, as I). A. D. Lindsay points out in his recent volume, "The Modern Democratic State", that industrial or economic organization is not just an instrument; it partly moulds the society which uses it. Some recognition of this truth lies behind the general belief that the measures open to unregulated and unaided private enterprise will not suffice to vary the incidence of the trade cycle and to maintain a constant and high level of employment, but that a national economic policy is required to deal with cyclical unemployment. Before, therefore, we can determine the right relations of government and industry in a democratic society, we must have clear conceptions not only of the nature of that society but also of the place and functions which government and industry are to serve in it. It is the confusion on this point that has darkened counsel in so many of the proposals and discussions on industrial self-government, planning and the public control of private enterprise and production. The distinction between government and management is often overlooked and Dr. Lindsay's volume is to be welcomed for its contribution to the clarification of the issues on this point alonea contribution which at least merits comparison with that of Prof. Ernest Barker's "Reflections on Government".

The leadership which industry has failed to supply is an essential in a society in which industry is to be a real social function, and the attention which has been directed to this point of late, notably in the statement on "Industry and Education" issued by Nuffield College, indicates that an attempt is being made to meet the need. If democracy is to survive, it will have to employ and use, as Dr. Lindsay truly remarks, every scrap of skill and knowledge and leadership it can secure. "A modern democratic state is only possible if it can combine appreciation of skill, knowledge and expertness with a reverence for the common humanity of everyday people."

That is the conception of equality which democratic

* Industry After the War: Who is Going to Run It? By Charles Madge, in consultation with Donald Tyerman. (Target for Tomorrow,
No. 1.) Pp. 64. (London: The Pilot Press, Ltd., 1943.) 38. 6d. net. institutions must express along with liberty. The function of the State being to serve the community and in that service to make it more of a community, a democratic government must be sensitively aware of the conditions which are making equality and liberty hard to maintain. There are clearly certain minimum rights and minimum standards of economic security which it must provide. But it must also be swift to diagnose and to deal with such obvious and outstanding evils as widespread unemployment, which so poison the life of a people that they make real community impossible.

In a democratic society this cannot be the task of the government only. The government must seek to enlist the help of all those free associations in which the life of society finds expression, and notably is this true of industry. The first step to self-government of industry is not so much freedom from government control as association and integration with the workers themselves. The joint production committees already set up in Great Britain may well be a step in this direction, and with a wise educational policy may so broaden the basis of recruitment that natural leaders are thrown up as they should be, and the closer integration of industry with the life of the community rendered possible.

Whether the joint production committees will provide exactly the type of machinery required to achieve this purpose requires further examination. They should be regarded as an experiment the results of which require study and comparison with those obtained in other experiments, for example, the autonomous groups of M. Dubreuil. Dr. Drucker has suggested a guild structure in industry, and unquestionably it should be one of our prime purposes to develop genuine local self-government in this sphere, to develop as Dr. Drucker urges, in "The Future of Industrial Man", social institutions in industry through which industry can become a functioning self-governing social community.

That would do much, by giving the individual industrial worker social status and function, to arrest the social atrophy which mechanization has often introduced. It would make also a decisive contribution to the establishment of the public confidence on which the Nuffield College statement rightly lays stress. Again, it is linked up with what Dr. Drucker considers the other essential in the establishment of a functioning society, namely, making the decisive social power into legitimate power, or in other words power derived from the consent of the governed. Clearly there is no surer way of gaining public confidence in the conduct of industry than the demonstration beyond question that it is directed to serve the needs of society and not merely the private interests of those who are engaged in it, whether they be investors, management or the workers as such. Misgivings on such points are in fact the main ground of uneasiness at present; they lead to the fear that price-fixing and restrictions on production are determined by considerations of private profit and not of public service and social needs.

The Nuffield College statement on "Industry and Education" does well to stress this factor of con- 
fidence, for only by such means can we ensure the full co-operation of workers, management and consumers that is essential both for efficient production in the technical sense and for the service of social needs. In this sense morale is no less important in the normal operation of industry than it is in the war effort. The success of post-war reconstruction policy, and in particular that directed to full employment, depends at least as much upon the standard of morale in industry and in the nation as a whole as does our ability to win the War.

Given, therefore, that one of our objectives should be to create conditions in which industry has the best chance of developing as a social service, and in doing so develop real self-government and co-operation between management and workers, we can consider the machinery by which that broad objective can best be achieved. If one of the essential functions of the State is to remove the disharmonies which threaten the common life of the community, the more positive and constructive functions which the government is rightly expected to perform make it difficult to draw a clear line between the functions of a modern government and those performed by voluntary associations. The essential problem is in fact to arrive at such a balance between voluntary association and the compulsory organization of the State as will ensure the maximum harmony in communal life while keeping the State as the servant and not the master of the community.

The clue to the right solution here is not hard to find. It is a great mistake to assume that the strength of a government is increased by adding to its powers, because additional powers always impose additional duties. There are tasks which only a central government can perform; and if it is to discharge those tasks well, it is important to devolve on local authori. ties or even on voluntary associations all the functions they can competently perform. In the decision to centralize authority the onus probandi should always rest with those urging centralization.

Much of the present dissatisfaction with the machinery of government in Great Britain can be traced to violation of this principle. Failure to delegate responsibility or authority effectively may well be responsible for the central government becoming immersed-doubtless with all the exigencies of the War in extenuation, if scarcely in excuse-in a mass of detail that has prevented it from considering those broad issues of policy and making the decisions, for example, in regard to land policy, planning and building which are required before local and regional authorities can proceed with the more detailed planning and execution which is their responsibility. The consequences in industry are similar. As both the Nuffield College statement and the Unilever paper show, there are fields in which the Government must announce its decisions and lay down the broad lines of policy before industry can make its own plans; and this is independent of the exact structure of industry, and whether it takes the form of private enterprise or State enterprise. Unemployment, investment policy and exports are all matters of this type where Government initia- tive, guidance and control are the first requisite. Unfortunately, Mr. Madge, in his "Industry After the War.", fails to discriminate between the control and management of industry. The difference is important. If a measure of public control is adopted for a particular industry, the management of industry in the sense of the technical conduct of its day-to-day affairs must still be efficient. The fears as to Government control are largely due to this confusion between control and management, and its removal must be one of the first steps to secure the effective integration of industry as a social activity, whether from the point of view of securing the co-operation of workers or the confidence of the public in general.

\section{INFANT MORTALITY}

Birth, Poverty and Health

A Study of Infant Mortality. By Richard M. Titmuss. Pp. 118. (London : Hamish Hamilton, Medical Books, Ltd., 1943.) 7s. 6d. net.

A MONG indexes of disease and death none offers A a more inviting field for research in the field of vital statistics than the infant mortality-rate. Its distribution among different social classes and different communities has an extremely high dispersion, and the general level within a single composite social group has unique features. While chances of death at other ages declined steadily during the whole of the last three quarters of the nineteenth century, both in Britain and in Western Europe as a whole, the death-rate under one year of age fluctuated about the same figure-150 per thousand for England and Wales-until about 1899. From 1900 there has been a continuous and spectacular change. During the subsequent half-century the number of infant deaths per thousand in our own country has fallen by more than sixty per cent. This being so, it is surprising that contributory social agencies have attracted so little inquiry to date. One reason is a hangover from an ideology widely current in the period when evolutionary concepts furnished a convenient rationale for an economy of unrestricted private competition and colonial misgovernment. What Sir Henry Maine called the "beneficent private war which makes one man strive to climb on the shoulders of another and remain there" was the prevailing creed of the universities when the existence of differential mortality first forced itself on public discussion. Foremost among articles of the creed was the postulate that class mortality and morbidity differences have their origin in differences of genetic constitution.

In conformity with a type of non-sequitur endemic in writings about what one calls eugenics on this side of the German Ocean and Rassenhygiene on the other side of the North Sea, differences which are inborn are also irremediable. By the same token, the probable existence of genes which affect resistance to smallpox would invalidate vaccination, and the certain existence of genes which affect susceptibility to cancer would veto radium therapy;: but there were too few who recognized this dilemma. Nineteenth century thought about heredity could not as yet see beyond a miasma of misconceptions arising from identification of character differences with genes which determine them within a particular environmental framework. This we may amply deduce from the writings of Galton, than whom few writers have more powerfully influenced, and more deplorably 